\title{
Mandatory role of proteinase-activated receptor $I$ in experimental bladder inflammation
}

\author{
Ricardo Saban*1, Michael R D'Andrea², Patricia Andrade-Gordon², \\ Claudia K Derian², Igor Dozmorov ${ }^{3}$, Michael A Ihnat ${ }^{4}$, Robert E Hurst ${ }^{5}$, \\ Carole A Davis ${ }^{1}$, Cindy Simpson ${ }^{1}$ and Marcia R Saban ${ }^{1}$
}

\begin{abstract}
Address: ${ }^{1}$ Department of Physiology, The University Oklahoma Health Sciences Center, Oklahoma City, OK 73104, USA, ${ }^{2}$ J\&J Pharmaceutical Research and Development Spring House, PA 19477-0776, USA, ${ }^{3}$ Oklahoma Medical Research Foundation (OMRF), Arthritis and Immunology Research Program, Microarray/Euk. Genomics Core Facility, Oklahoma City, Oklahoma 73104, USA, ${ }^{4}$ Department of Cell Biology, The University Oklahoma Health Sciences Center, Oklahoma City, OK 73104, USA and ${ }^{5}$ Department of Urology, The University Oklahoma Health Sciences Center, Oklahoma City, OK 73104, USA

Email: Ricardo Saban* - ricardo-saban@ouhsc.edu; Michael R D'Andrea - mdandrea@prdus.jnj.com; Patricia Andrade-

Gordon - pandrade@prdus.jnj.com; Claudia K Derian - cderian@prdus.jnj.com; Igor Dozmorov - igor-dozmorov@omrf.ouhsc.edu; Michael A Ihnat - Michael-inhat@ouhsc.edu; Robert E Hurst - Robert-hurst@ouhsc.edu; Carole A Davis - carole-davis@ouhsc.edu; Cindy Simpson - cindy-simpson@ouhsc.edu; Marcia R Saban - Marcia-saban@ouhsc.edu

* Corresponding author
\end{abstract}

Published: 30 March 2007

BMC Physiology 2007, 7:4 doi:10.1 186/1472-6793-7-4
Received: 16 November 2006

Accepted: 30 March 2007

This article is available from: http://www.biomedcentral.com/1472-6793/7/4

(C) 2007 Saban et al; licensee BioMed Central Ltd.

This is an Open Access article distributed under the terms of the Creative Commons Attribution License (http://creativecommons.org/licenses/by/2.0), which permits unrestricted use, distribution, and reproduction in any medium, provided the original work is properly cited.

\begin{abstract}
Background: In general, inflammation plays a role in most bladder pathologies and represents a defense reaction to injury that often times is two edged. In particular, bladder neurogenic inflammation involves the participation of mast cells and sensory nerves. Increased mast cell numbers and tryptase release represent one of the prevalent etiologic theories for interstitial cystitis and other urinary bladder inflammatory conditions. The activity of mast cell-derived tryptase as well as thrombin is significantly increased during inflammation. Those enzymes activate specific G-protein coupled proteinase-activated receptors (PAR)s.

Four PARs have been cloned so far, and not only are all four receptors highly expressed in different cell types of the mouse urinary bladder, but their expression is altered during experimental bladder inflammation. We hypothesize that PARs may link mast cell-derived proteases to bladder inflammation and, therefore, play a fundamental role in the pathogenesis of cystitis.

Results: Here, we demonstrate that in addition to the mouse urinary bladder, all four PA receptors are also expressed in the $J 82$ human urothelial cell line. Intravesical administration of PAR-activating peptides in mice leads to an inflammatory reaction characterized by edema and granulocyte infiltration. Moreover, the inflammatory response to intravesical instillation of known pro-inflammatory stimuli such as E. coli lipopolysaccharide (LPS), substance P, and antigen was strongly attenuated by PARI-, and to a lesser extent, by PAR2-deficiency.

Conclusion: Our results reveal an overriding participation of PARI in bladder inflammation, provide a working model for the involvement of downstream signaling, and evoke testable hypotheses regarding the role of PARs in bladder inflammation. It remains to be determined whether or not mechanisms targeting PARI gene silencing or PARI blockade will ameliorate the clinical manifestations of cystitis.
\end{abstract}




\section{Background}

In general, inflammation plays a role in most bladder pathologies, including bladder cancer [1-4] and represents a defensive reaction to injury caused by physical damage, chemical substances, micro-organisms, or other agents $[1,2]$. In particular, bladder neurogenic inflammation involves the participation of mast cells and sensory nerves. Evidence for a role of mast cells in cystitis was reviewed recently [5] and includes the presence of mast cells containing tryptase in the bladder [6] and urine of IC patients [6,7], and that mast cell counts in IC patients are one of the few features significantly associated with nighttime frequency of urination [8]. We have previously presented direct evidence indicating a key role for mast cells and their products in bladder inflammation [9-11], and others emphasized the role of mast cell products in bladder disorders [12-14].

As a consequence of inflammation, products of mast cell degranulation, such as tryptase, can be found in the urine of cystitis patients [15]. In addition to tryptase, other serine proteases such as thrombin and trypsin are produced during tissue damage and make important contributions to tissue responses to injury, repair, cell survival, inflammation [16-19], and pain [20-24]. Tissue responses to these enzymes are modulated by protease-activated receptors (PARs), a unique class of $\mathrm{G}$ protein-coupled receptors that use a fascinating mechanism to convert an extracellular proteolytic cleavage event into a trans-membrane signal. These receptors carry their own ligands, which remain cryptic until unmasked by receptor cleavage (for a review, please see references $[20,23,25,26])$.

Four PARs have been cloned so far, and all four PARs are co-expressed in the mouse bladder urothelium [27], with PAR2 and PAR3 being the most abundant in the bladder epithelial layer. Although information regarding the presence of PARs in human urothelial cells is scanty, indirect evidence indicates that human cancer urothelial cells, such as J82, augment the conversion of prothrombin to thrombin, a key activator of PARs [28]. In addition, thrombin and other elements of the coagulation cascade activate J82 carcinoma cells, inducing $\mathrm{Ca}^{2+}$ mobilization, phospholipase C activity, and cell migration [29]. Another human bladder cell line, RT4, responds to thrombin, tryptase or PAR-APs with an increase in intracellular phospholipase $\mathrm{A}_{2}$ activity, arachidonic acid and prostaglandin $\mathrm{E}_{2}$ release [30]. In this work, we determined whether all four receptors are present in the human urothelial J82 cell line.

In addition to the urothelium, PAR1 and PAR2 are also expressed in mouse detrusor muscle, and PAR4 is expressed in mouse peripheral nerves and plexus cell bodies [27]. Similarly, in rats PAR2, 3, and 4 are expressed in urothelium, detrusor muscle, and bladder nerve fibers, and bladder afferent cells in dorsal root ganglia express PAR2 to 4 [31]. Confocal microscopy has revealed the colocalization of PAR2, 3, and 4 with protein gene products 9.5 and vanilloid receptor 1 , suggesting that PARs are distributed in C-fiber bladder nerves [31]. In addition, PARs are differentially modulated during mouse bladder inflammation. Urothelial PAR2 and, to a lesser extent, PAR1 are down-regulated in acute inflammation whereas PAR3 and PAR4 are up-regulated [27]. Bladder fibroblasts were found to present a clear demarcation in PAR expression in response to acute and chronic inflammation [27]. Additional evidence for the participation of PARs in the bladder inflammatory response was the finding that known pro-inflammatory stimuli such as LPS, substance $\mathrm{P}$, and antigen challenge induce an increase in PAR4 RNA within four hours [32]. Upregulation of PAR protein levels have been shown to be part of rat bladder responses to cyclophosphamide [31].

In order to better understand the role of PARs in cystitis, we used a well-established mouse model $[1,2,26]$ to determine the relative potency of PAR-activating peptides (PAR-APs). PAR3-AP was not included in this research because of a lack of specificity of the available reagent. Comparison of inflammatory responses in wild type, PAR1- and PAR2-deficient mice, revealed a mandatory role of PAR1 and, to a lesser extent, PAR2 in mediating bladder responses to a variety of pro-inflammatory stimuli.

The combination of morphological results reveals an overriding participation of PAR1 receptors in bladder inflammation and provides a working model to investigate the inflammatory cascade downstream of PAR activation.

\section{Results}

\section{Human urothelial cell line expresses all four PARs}

In order to extend our previous results obtained with the mouse bladder [27], we also tested the presence of PA receptors in the J82 human urothelial cancer cell line. Our results indicate all four PARs are detectable at the protein level by immunohistochemistry (Figure 1A-E) and at the message level by polymerase chain reaction (Figure 2A-B) in human urothelial cancer cell line.

\section{PAR-APs induce bladder inflammation}

Next, we determined whether activation of PARs in mice would induce bladder inflammation. Figure 3 shows a representative photomicrograph demonstrating that an inflammatory response was mounted twenty-four hours after bladder instillation with PAR4-AP $(10 \mu \mathrm{M})$. Inflammation secondary to PAR4-AP was characterized by vasodilation (Figure 4A), sub-epithelial infiltration of 

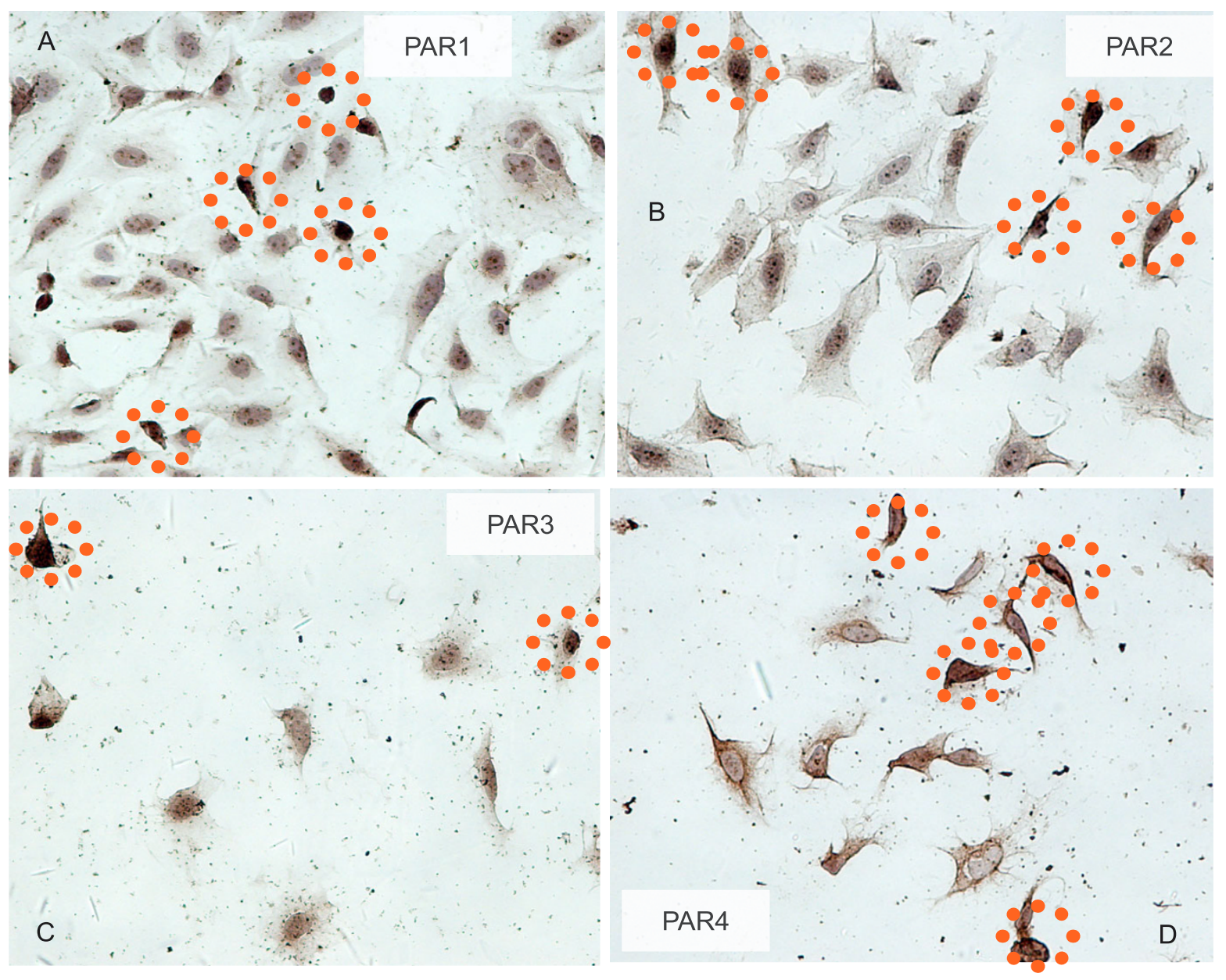

PAR4

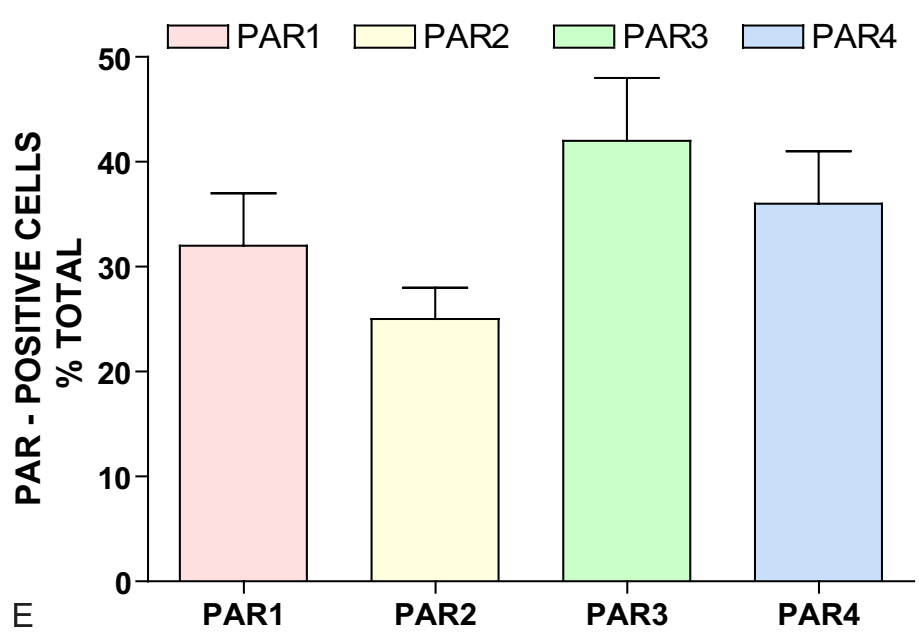

Figure I

A-E. PAR immunohistochemistry in 182 human urothelial carcinoma cell line. Representative photomicrograph obtained in J82 cell line stained with PAR specific antibodies. 382 cells were fixed and incubated with primary polyclonal (Santa Cruz Biotechnology, Santa Cruz, CA) antibodies: A = PAR-I (I:20), B = PAR-2 (I:I00), C = PAR-3 (I:5), and D = PAR-4 (I:50). Slides were washed and incubated with biotinylated secondary antibodies (Vector Labs), goat anti-rabbit (polyclonal antibodies). Orange dotted circles highlight some cells considered positives for the particular receptor. Original magnification was $\times 200$. Figure IE represents the average and SEM of number of PAR-positive cells as percent of the total cells per field. 

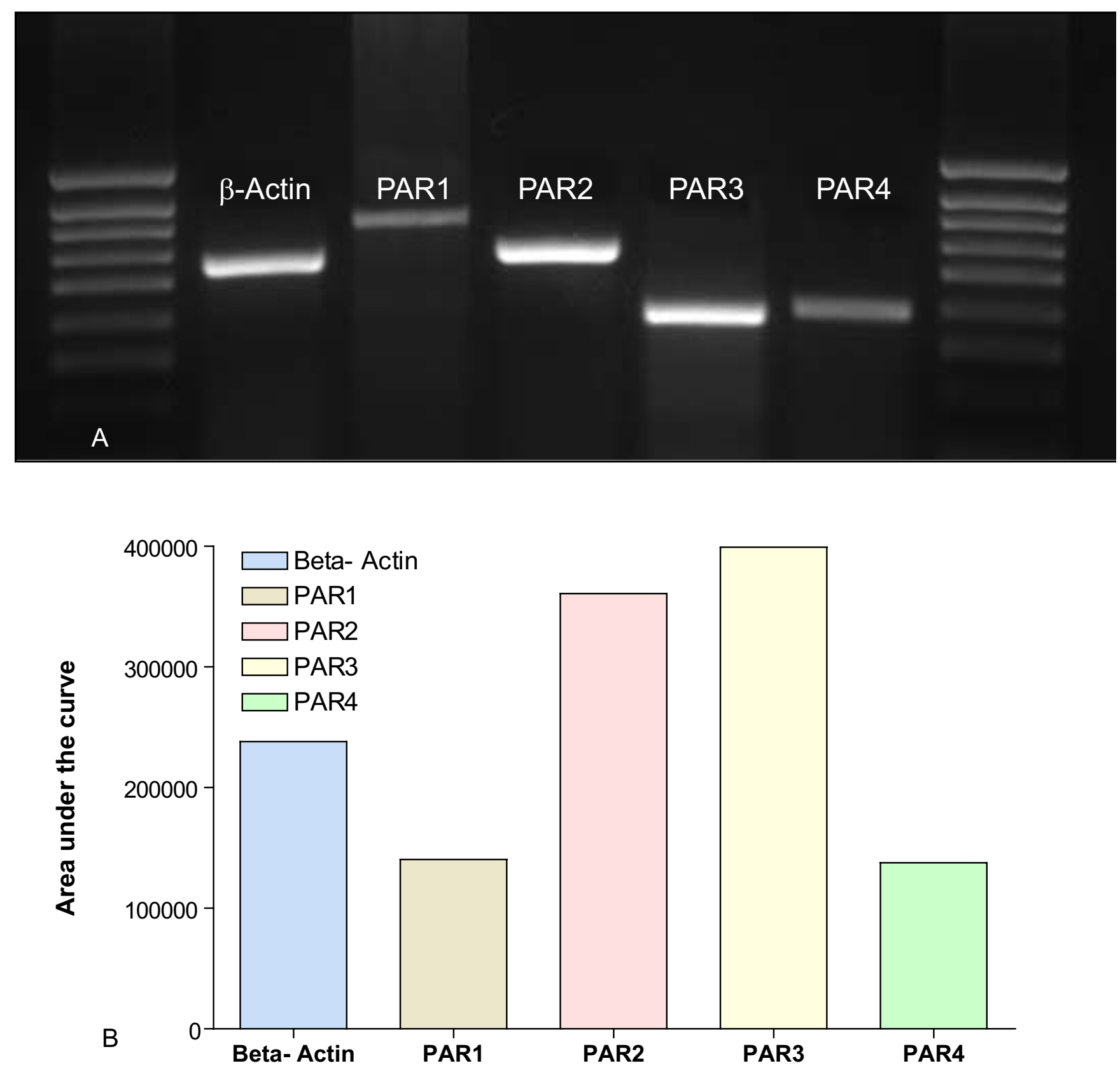

Figure 2

A-B. Polymerase Chain Reaction for detection of PARs message in $J 82$ human urothelial carcinoma cell line. Figure $2 \mathrm{~A}$ is a photomicrograph of the gel and Figure 2B represents the area under the curve as quantified using Image J software [74]. Primers used in this experiment are described in additional file I (Table I).

inflammatory cells (Figure 4B), and edema (Figure 4C). A high magnification photomicrograph (Figure 4D) indicates that the majority of inflammatory cells responding to PAR4-AP were polymorphonuclear [PMNs] leukocytes characteristic of acute bladder inflammation [32]. In addi- tion, the cellular infiltrate expanded from submucosal layers towards the detrusor smooth muscle (green arrows in figure $3 \mathrm{~A}$ ) and within the detrusor nerve elements, previously shown to contain PAR4 (figure 9 of the reference [27]), are surrounded by inflammatory cells. Similar 
results were obtained 48 hours after bladder instillation with PAR4-AP with the addition of macrophages to the lesion (data not shown).

Next, we compared the effect of $10 \mu \mathrm{M}$ concentrations of PAR1-AP, PAR2-AP, and PAR-4-AP on the degree of PMN infiltration into the urinary bladder. The representative photomicrographs on figure 4 indicate that contrast to the control peptide which failed to induce bladder inflammation (Figure 5A), PAR1- (Figure 5B), PAR2- (Figure 5C), and PAR4-AP (Figure 5D) induced different densities of inflammatory cell infiltrate. Figure 6 summarizes the results obtained with different concentrations of PAR-APs. An inflammatory cell infiltrate was detected at concentrations as low as $0.1 \mu \mathrm{M}$ and reached a peak at $10 \mu \mathrm{M}$ PAR4$\mathrm{AP}$. These results indicate that, at least in the mouse bladder, the instillation of $10 \mu \mathrm{M}$ PAR4-AP or $100 \mu \mathrm{M}$ PAR1$\mathrm{AP}$ induces a strong inflammatory reaction characterized by the highest number of PMNs infiltrating the bladder. Both PAR1-AP and PAR2-AP at $10 \mu \mathrm{M}$ concentration induced bladder inflammation but the number of PMNs that infiltrated the urinary bladder was smaller than that observed with PAR4- AP $(10 \mu \mathrm{M})$. No inflammation was observed in mice instilled with pyrogen-free saline or 10 $\mu \mathrm{M}$ control peptide dissolved in PBS.

PAR $1 \%$ and PAR2 $\%$ mice were used to determine whether those receptors were downstream of a common inflammatory cascade. We chose the following classical inflammatory stimuli: substance P, LPS, and antigen-challenge (in sensitized mice) because they were shown to depend on mast cells for eliciting bladder inflammation $[7,8,27]$, and products of mast cell degranulation such as chymase and tryptase activate PAR1 $[33,34]$ and PAR2 receptors $[35,36]$, respectively. For this purpose, groups of anesthetized female, wild type (C57BL/6J), PAR $1 \%$, and PAR2 $\%$ mice $(n=6-8)$ were instilled with saline, or with control inactive peptide $(10 \mu \mathrm{M})$, or one of the following substances at concentrations known to induce inflammatory response [32]: substance P $(10 \mu \mathrm{M})$, Escherichia coli LPS strain 055:B5 $(100 \mu \mathrm{g} / \mathrm{ml})$, DNP4-OVA (in sensitized mice; $1 \mu \mathrm{g} / \mathrm{ml})$, PAR1-AP $(10 \mu \mathrm{M})$, and PAR2-AP $(10 \mu \mathrm{M})$. Twenty-four hours later, bladders were removed for quantification of PMN infiltration. Figures 7A and 7B summarize the results obtained. PAR $1 \%$ mice presented a reduced response to substance $\mathrm{P}$, LPS, and antigen stimulation (Figure 7A). However, the responses to PAR2-AP obtained in PAR1\% mice were not altered (Figure 7B). The major difference between PAR $1 \%$ and PAR2 $\%$ mice is that the latter still presented an inflammatory response to antigen (Figure 7A).

Regarding other inflammatory cells, bladders isolated from PAR $1 \%$ and PAR2 $\%$ presented equivalent number of mast cells when compared to wild type mice (mast cell/ cross section: PAR1 $\%=9.7 \pm 1.1 ;$ PAR2 $\%=11.7 \pm 1.9$; wild type $=8.3 \pm 0.6 ; p$ values $=0.30$ when comparing $\mathrm{WT}$ to PAR $1 \%$ and $p=0.10$ when comparing WT to PAR2 $\%$ animals). After stimulation with the pro-inflammatory stimuli, the bladder of wild type mice presented signs of mast cell activation by the presence of degranulation. In contrast, except for some perivascular infiltrate, few inflammatory cells were seen in the bladder of PAR $1 \%$ mice in response to pro-inflammatory stimuli (data not shown). In addition, when mast cells were visible, there was no apparent sign of degranulation, which may reflect poor activation of those cells (data not shown).

These results indicate that PAR1 receptors are essential for bladder inflammation secondary to several pro-inflammatory stimuli, while PAR-2 receptors seem to have a decreased role, at least in mediating the responses to antigen challenge. Because the transgenic mouse models used have been reported to be complete knockouts [18,37-42] and PAR2-AP has no effect on PAR2 knockout mice $[43,44]$, we did not test PAR1-AP in PAR1/-and PAR2-AP in PAR2 $\%$ mice.

\section{Discussion \\ Role of PAR in bladder inflammation}

Proteases that are released during inflammation and injury cleave PARs on the urothelium, detrusor muscle, and nerve elements to cause neurogenic bladder inflammation $[45,46]$ and hyperalgesia $[21,23]$. As we demonstrated earlier by IHC, PARs are over-expressed in the bladder following cystitis induced by classical mediators such as LPS and SP [27].

This study determined whether all four PAR receptors are expressed in human urothelial cell line. The presence of multiple PARs on the same cell is thought to extend the range of proteases a cell responds to rather than expand the range of intracellular responses [30]. Human transitional-cell carcinoma (J82) cells express various G protein-coupled receptors, and the presence of PARs in this cell line was based on the effects of thrombin, which induces a strong migration of J82 cells by a mechanism that involves $\mathrm{Ca}^{2+}$ mobilization and activation of Rho kinase leading to a reorganization of the cytoskeleton [29]. In addition to the J82 cell line, expression of PARs in RT4 bladder papilloma cells was inferred based on findings that RT4 cells respond to activators of PARs such as thrombin, tryptase, and PAR-activating peptides[30]. Those PAR activators induced a calcium independent phospholipase $\mathrm{A}_{2}$ with the consequent release of arachidonic acid and synthesis of prostaglandin $\mathrm{E}_{2}$ [30]. Since the presence of PARs in human urothelium was only based on circumstantial evidence, we determined whether J82 carcinoma cell line expresses PAR protein and RNA. 


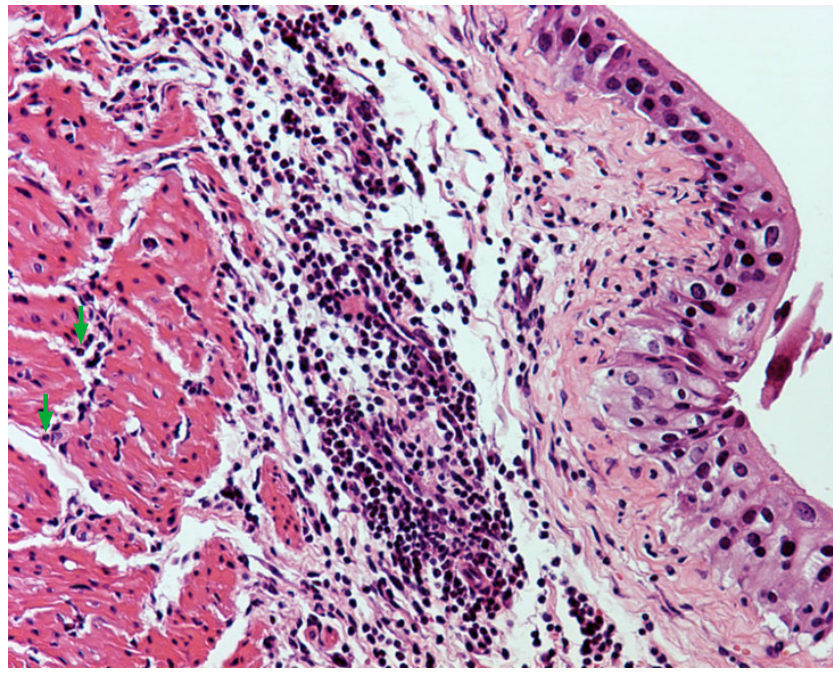

\section{Figure 3}

PAR4-AP induces bladder inflammation. Anesthetized female C57BL6 mice were catheterized, the bladder was emptied, and a volume of $200 \mu$ l of a solution of PAR4-AP $(10 \mu \mathrm{M})$ was instilled into the urinary bladder. Twenty four hours later, bladders were removed, processed for histology, and stained with H\&E. At low magnification, photomicrograph illustrates the distribution of inflammatory cells extending from the submucosa to deep regions in the detrusor smooth muscle (green arrows). Magnifications $=\times 100$

Our results demonstrate that the J82 human urothelial cell line expresses all four PA receptors.

An additional goal of this paper was to determine whether PA receptors are part of the inflammatory cascade mediating the response of the urinary bladder to known proinflammatory stimuli. The stimuli were chosen because we have published evidence that each one of them when instilled into the mouse bladder produces inflammation: substance P [47], LPS [48], and antigen challenge of sensitized mice $[10,11]$. However, the present manuscript did not determine which endogenous substance is responsible for activation of PAR receptors, and therefore, the following discussion is based on the literature and not in the results of this manuscript. The information regarding endogenous activators of PARs in the mouse bladder is, unfortunately, scanty. While human connective tissue mast cells contain the enzymes chymase and tryptase, mice contain numerous related proteases [49-51]. Mouse mast cell protease- 7 is a tryptase predominantly expressed in differentiated connective tissue-type mast cells [52]. Mast cell proteases mcpt5 (chymase), mcpt 6 and 7 (tryptases) are expressed during the development of the mouse embryo [49]. However, to the best of our knowledge, there is no information regarding which particular tryptase is expressed in the mouse bladder and/or upregulated in this mouse model during inflammation. Although thrombin is a recognized physiological activator of PAR1 and PAR4, the endogenous enzymes responsible for activating PAR2 in urinary bladder are not known. Recently, it was demonstrated that the tissue kallikrein family of proteinases are able to regulate PAR signaling and may represent important endogenous regulators PAR1, PAR2, and PAR4 [53]. The latter are likely to be confirmed in the urinary tract, since members of the kallikrein family play a fundamental role in bladder physiology [54].

Administration of PAR peptide agonists into the urinary bladder of mice elicited an inflammatory reaction characterized by edema and granulocyte infiltration. Interestingly, the inflammatory responses to PAR4-AP peaked at $10 \mu \mathrm{M}$ and higher concentrations of this peptide (100 $\mu \mathrm{M})$ failed to produce an additional increase in PMNs migration, but rather induced a lesser degree of inflammation. Several possibilities could explain this finding, including PAR desensitization and endocytosis [55], shedding of these receptors from the cells, as is the case of PAR1 in endothelial cells exposed to thrombin [56], and shedding of urothelial cells bearing these receptor, as we suggested [27]. Although we observed a potent inflammatory response secondary to PAR4-AP, PAR4\%-mice were not available in our laboratory at the time this project started. Nevertheless, our results emphasize the importance of this receptor in cystitis.

In the present work, we determined that PAR $1 \%$ and, to a lesser extent, PAR2 $\%$ mice present decreased inflammatory responses to pro-inflammatory stimuli. The results obtained with PAR-deficient mice provide evidence indicating that substances known to stimulate mast cells, such as SP and antigen, induce a bladder inflammatory reaction that depends on PAR activation. In addition, these results indicate that toxins such as LPS, known to be released during bladder infection, also share the same PAR pathway.

The authors acknowledge the lack of functional data on in vivo urinary bladder function at this time. In vitro experiments indicate that both trypsin and PAR-2 activating peptide (SLIGRL-NH(2)) produced a concentrationdependent contractile response in the rat urinary bladder preparations. These contractions were abolished by removal of the urinary bladder mucosa and were significantly reduced by the non-steroidal anti-inflammatory drug indomethacin [57]. The release of prostaglandins by PAR-2 activators seems to be partly mediated by the phospholipase $\mathrm{A}_{2}$ (iPLA2) [58]. These responses were enhanced in bladders isolated from cyclophosphamidetreated rats [45]. The in vitro work confirms the evidence that PAR activation leads to iPLA2-mediated prostaglandin release in human urothelial carcinoma cell line RT4 

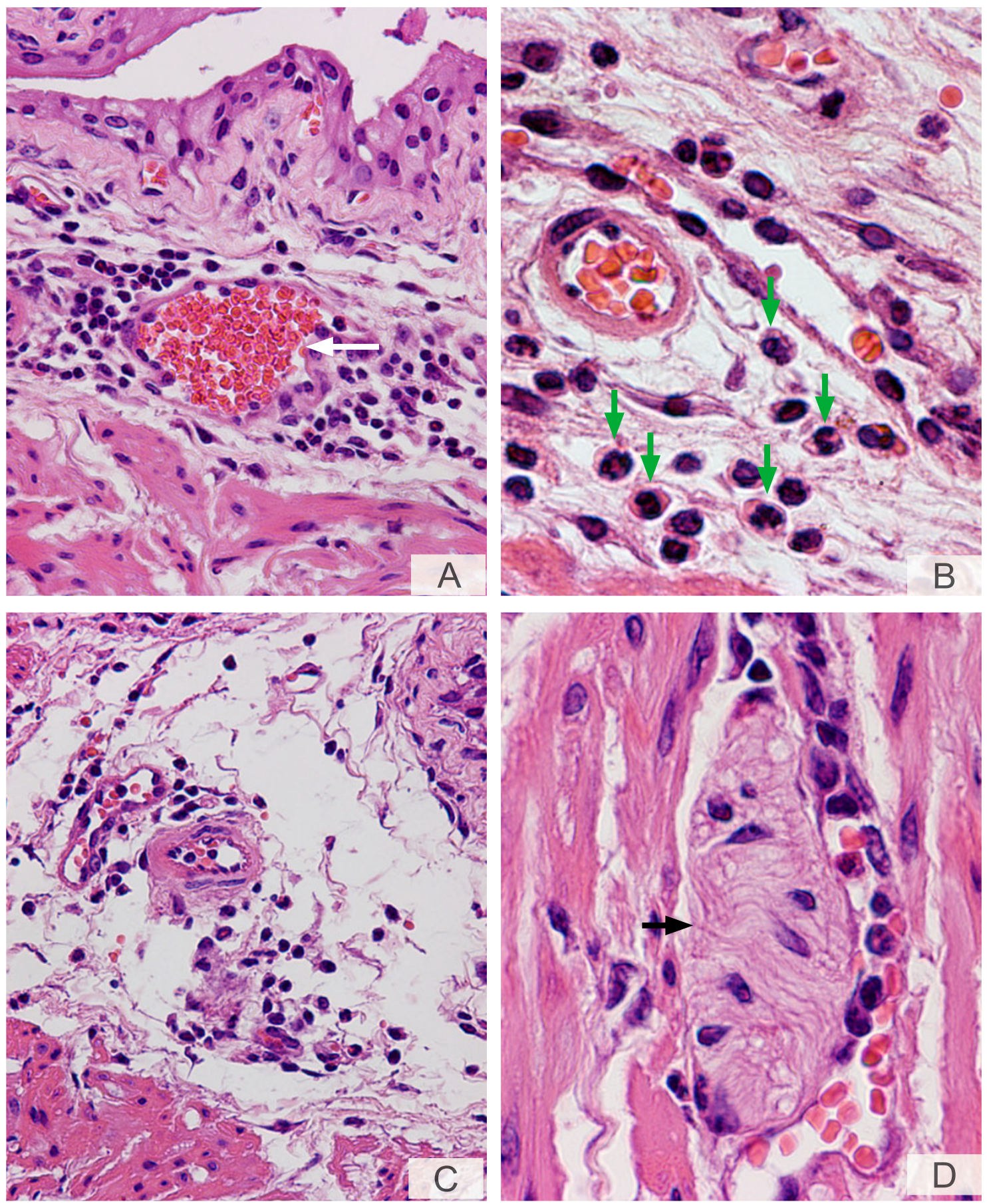

\section{Figure 4}

A-D. PAR4-AP induces bladder inflammation. Anesthetized female C57BL6 mice were catheterized, the bladder was emptied, and a volume of $200 \mu \mathrm{l}$ of a solution of PAR4-AP $(10 \mu \mathrm{M})$ was instilled into the urinary bladder. Twenty four hours later, bladders were removed, processed for histology, and stained with H\&E. A characteristic photomicrograph represents sub-urothelium inflammatory infiltrate around a blood vessel $(A)$ and dilation of blood vessels (white arrow). At higher magnification (B), it was possible to visualize that the majority of inflammatory cells in response to PAR4-AP presented a characteristic "doughnut" shape indicative of mouse PMNs (green arrowhead). The submucosal edema is illustrated in C. Figure 4D illustrates inflammatory cells surrounding a structure resembling a nerve element (black arrow). Magnifications $A=\times 200, B=$ $\times 400, C=\times 200$, and $D=\times 400$. 

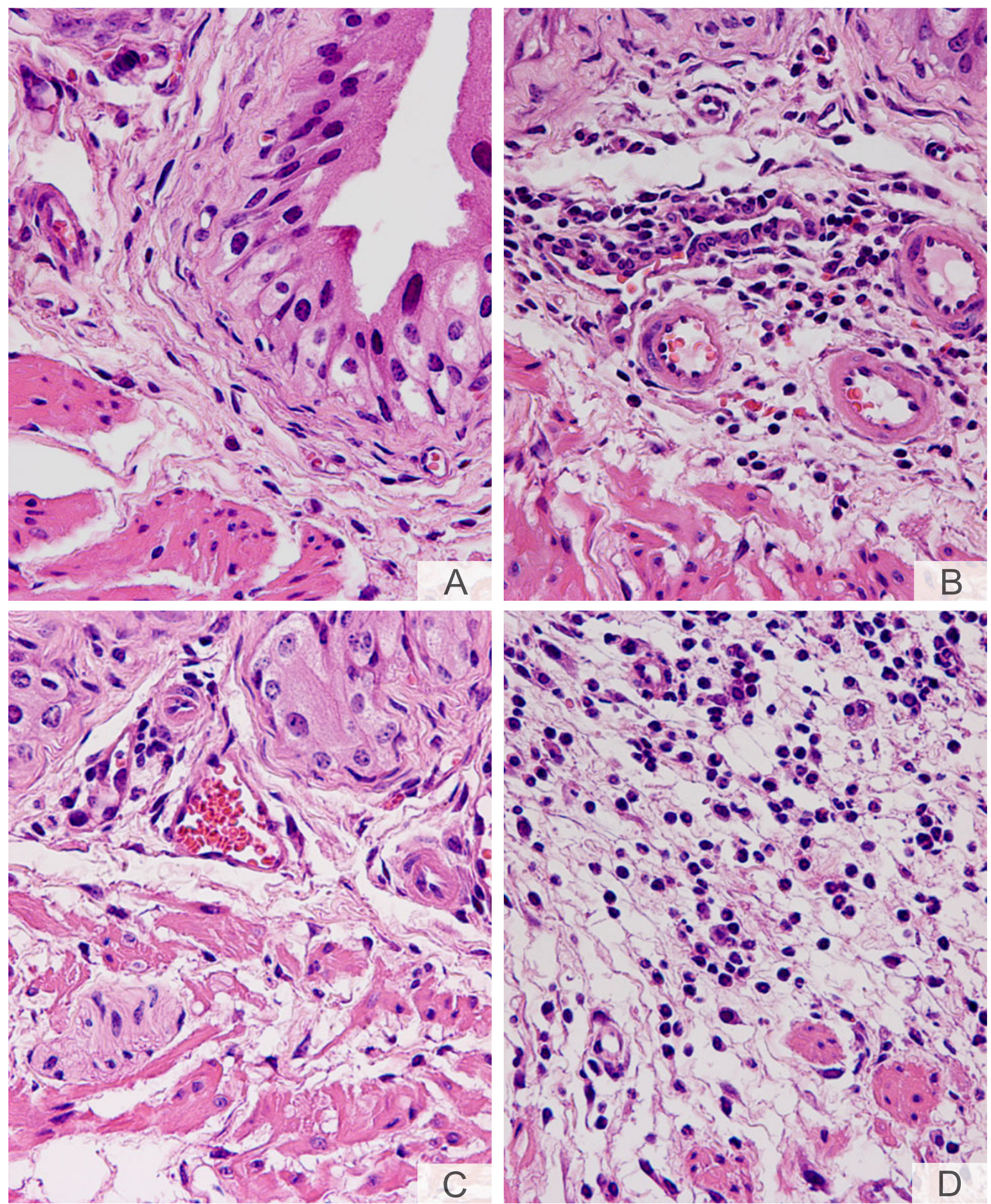

Figure 5

A-D. Comparison of different PAR-APs in inducing mouse bladder inflammation. Characteristic photomicrographs of bladders removed from female C57BL6 mice that received instillation of (A = control peptide; $B=$ PARI-AP; $C=P A R 2-A P$, and $D=$ PAR4-AP). All peptides were at the concentration of $10 \mu \mathrm{M}$ and bladders were removed 24 hours after challenge. Of note, absence of inflammation following instillation with control peptide $(A)$, submucosal PMN infiltrate induced by PAR I-AP (B), modest perivascular infiltration in response to PAR2-AP (C), and overwhelming PMN infiltration in response to PAR4-AP (D). Magnifications: A, B, C, and D $=\times 200$. 


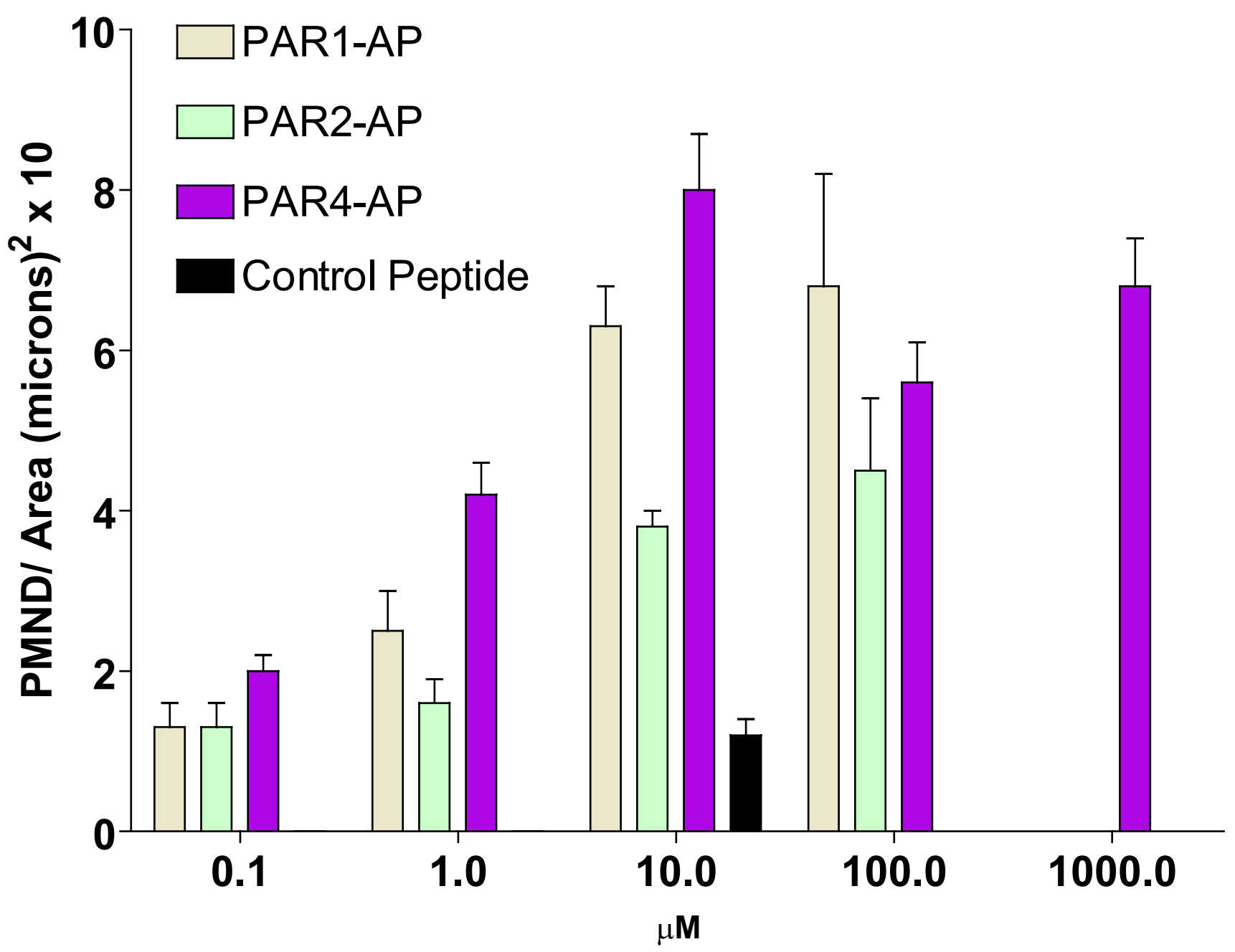

Figure 6

Effect of different concentrations of PARI-, PAR2-, and PAR4-AP on PMNs migration. Anesthetized female C57BL6 mice were catheterized, the bladder was emptied, and a volume of $200 \mu \mathrm{l}$ of a solution of control peptide (I0 $\mu M$ ) or PARI -, PAR2-, and PAR4-AP at different concentrations ( 0.1 to $1000 \mu \mathrm{M})$ was instilled into the urinary bladder. The number of PMNs migration into the mouse bladders was examined 24 hours after instillation $(n=8$ for PAR4-AP and control peptide and $\mathrm{n}=4$ for PARI-AP and PAR2-AP).

[30], human bladder microvascular endothelial $[59,60]$, and normal urothelial cells [61]. However, there is no in vivo functional data on the effect of PAR stimulation on bladder urodynamic behavior.

It is not clear why the experimental cystitis in PAR2 $\%$ mice was not totally abolished, as seen in PAR $1 \%$. Both PAR1 $\%$ - and PAR2 $\%$ mice have been well characterized $[18,37$ 42]; see $[62,63]$ for reviews. In addition, PAR2-AP has no effect on PAR2 knockout mice $[43,44]$. Nevertheless, compensatory mechanisms from other PA receptors could be possible. Regarding the difference of response between
PAR $1 \%$ and PAR2 \% mice, this may reflect a different role of the endogenous ligand since PAR1 is activated by thrombin, while PAR2 is activated by mast cell tryptase [23]. It has to be taken into consideration that some of the PAR agonists, such as thrombin, activate more than one receptor. Indeed, in addition to PAR1, thrombin activates PAR4 [20] and type-II TGF $\beta$ receptors and consequently leads to their down regulation [64]. PAR1 [65] and possibly PAR3 and PAR4 are involved in vascular inflammation, but the primary role for PAR2 seems to be cytoprotection in the gastro intestinal tract $[66,67]$ and airways [68]. It was reported that whereas PAR1 $\%$ mice do 

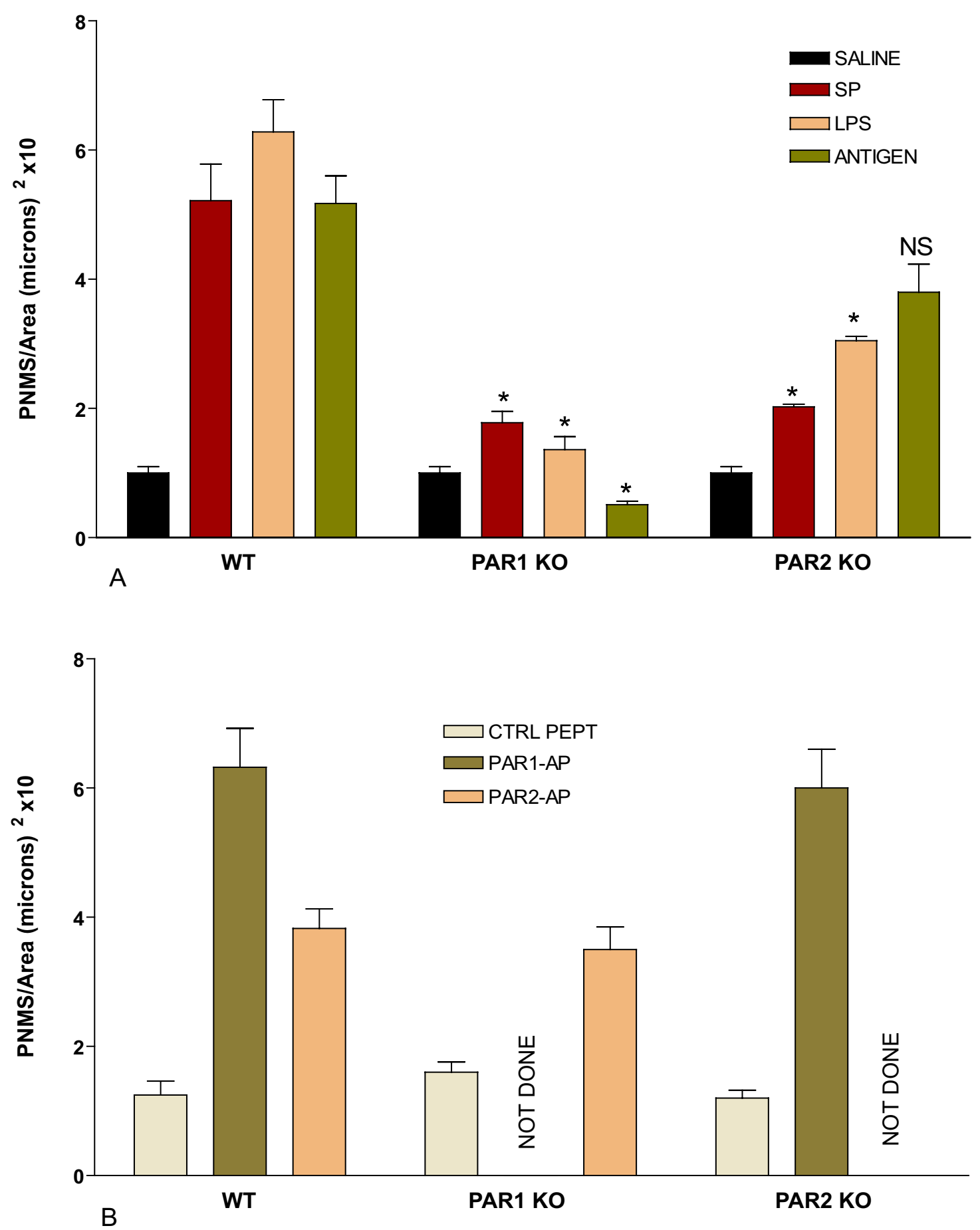

\section{Figure 7}

A-B. Comparison of the inflammatory responses (PMNs infiltration) obtained with wild type (C57BL/6J), PARI-/-, and PAR2 ${ }^{-/-}$ mice. Responses were obtained 24 hours after bladder instillation with one of the listed substances. Figure 7A represents the response to substance $\mathrm{P}(\mathrm{I} 0 \mu \mathrm{M})$, Escherichia coli LPS strain 055:B5 (I00 $\mu \mathrm{g} / \mathrm{ml})$, and DNP4-OVA (in sensitized mice; I $\mu \mathrm{g} / \mathrm{ml})$ compared to saline (black bars). Figure 7B represents the responses to PARI-AP (I0 $\mu M)$ and PAR2-AP (I0 $\mu M)$ compared to control inactive peptide $(10 \mu \mathrm{M})$. Number of mice $=6-8$ per group. NS= not significant. Asterisks represent a statistically significant difference $(P<0.05)$ between the responses obtained with each pro-inflammatory stimuli in PARI-/- or PAR2-/- and the respective response obtained in wild type mice. 
not mount inflammatory responses to a variety of stimuli, PAR2 \%- mice present a delayed microvascular inflammation [40] and a reduced encephalomyelitis [69].

Another possible explanation for the discrepancy between PAR1 and PAR2 is the differential localization of the two PARs in urinary bladder. PAR2 is much more abundant than PAR1 in the urothelium. However, following acute and chronic inflammation, probably because of the shedding of urothelial cells bearing PARs, both PAR1 and PAR2 expression are reduced [24]. Alternatively, the association between PAR1 and PAR2 with vallinoid receptors [70] in sensory $C$ fibers deserves further investigation as a possible explanation for a differential participation of PAR1 and PAR2 in inflammation. Another hypothesis points to the control of PAR by a metalloproteinasedependent shedding of proteins from the cell surface [56]. More recently, it has been shown in humans that the downstream signal transduction cascade in response to PAR2 but not PAR1 depends on an interacting partner, the Jun activation domain-binding protein 1 (Jab1) [71]. Taken together, data from literature suggests a differential fate for PAR1 receptor as compared to PAR2 receptor, which could help to explain the difference in response to inflammatory stimuli in the bladder of PAR1\% versus PAR2 /- mice. Regardless of the receptor type, our findings demonstrate an overwhelming participation of PARs in bladder inflammation and place them in a central role controlling the communication between the immune system represented by mast cells, the sensory system represented by SP, and infection represented by LPS.

\section{Conclusion}

This work indicates an overriding participation of PAR1 receptors in bladder inflammation, provides a working model for the involvement of a network of transcripts downstream of PAR1 activation, and evokes testable hypotheses regarding the regulation of PAR. It remains to be determined whether PAR1 receptor blockade or selective gene silencing of transcripts downstream of PAR activation will ameliorate the clinical manifestation of cystitis. Inhibiting of PAR up-regulation using small interfering RNA technology, as confirmed by immunoblotting, should substantially reduced bladder inflammatory response as it has been shown in other systems [36].

\section{Methods}

\section{Human Urothelial Cell Culture}

Human bladder carcinoma cell line J82 (HTB-1) were obtained from the American Tissue Culture Collection. J82 cells were seeded onto a 4-chambers slide and cultured in Minimum Essential Media (MEM), supplemented with $10 \%$ fetal bovine serum (FBS), $100 \mu \mathrm{M}$ nonessential amino acids, $1 \mathrm{mM}$ sodium pyruvate, $100 \mathrm{U} / \mathrm{ml}$ penicillin/streptomycin and $2 \times$ MEM Vitamin Solution.
Cells were maintained at $37^{\circ} \mathrm{C}$ in a humidified atmosphere containing $5 \% \quad \mathrm{CO}_{2}$ until $90 \%$ confluence was reached. The medium was removed and cells were fixed in $10 \%$ formalin.

\section{PARs IHC in human cell line}

Fixed cells were processed for routine immunohistochemistry according to published methods [27]. All reagent incubations (30 $\mathrm{min}$ ) and washes were performed at room temperature. Normal blocking serum (Vector Labs, Burlingham, CA) was placed on all slides for $10 \mathrm{~min}$ and, after a brief rinse in PBS, sections were incubated with primary polyclonal (Santa Cruz Biotechnology, Santa Cruz, CA) antibodies: PAR-1 (1:20), PAR-2 (1:100), PAR-3 (1:5), and PAR-4 (1:50). Slides were washed and incubated with biotinylated secondary antibodies (Vector Labs), and goat anti-rabbit (polyclonal antibodies). After rinsing in PBS, the avidin-biotin-horseradish peroxidase complex reagent (ABC-HRP, Vector Labs) was added. Slides were washed and treated with the chromogen 3,3'diaminobenzidine (DAB, Biomeda, Foster City, CA) (two changes, 5 min each), rinsed in $\mathrm{dH}_{2} \mathrm{O}$, counterstained with hematoxylin, dehydrated, and coverslipped with Permount (Fisher Scientific) mounting media. Positive cells were visualized by microscope (Eclipse E600, Nikon, Lewisville, TX). All tissues were photographed at room temperature by a digital camera (DXM1200; Nikon). Five random fields per slide were counted. Images were analyzed with Image-Pro Analyzer ${ }^{\otimes}$ (Media Cybernetics Inc.; Silver Spring, MD). The number of positive cells per field at $200 \times$ magnification was calculated as percent of the total cells $(200 \times$ magnification $)$. Results are presented as average and standard error of the mean.

\section{PARs Polymerase chain reaction assay (PCR) in human cell line}

Total RNA was extracted in Ultraspec RNA solution (Biotecx Laboratories Inc. Houston, TX) according to the manufacturer's instructions. The amount and quality of the RNA were verified by measuring the absorbance at 260 and $280 \mathrm{~nm}$, and by electrophoresing the samples on a formaldehyde/agarose gel. Oligo(dT)-primed reverse transcription of RNA was performed with the SuperScript First-Strand Synthesis System for reverse transcriptasepolymerase chain reaction (RT-PCR) (Invitrogen, Carlsbad, CA), using $5 \mu \mathrm{g}$ of RNA for each reaction. Following reverse transcription, PCR amplifications were performed from $2 \mu \mathrm{l}$ of each cDNA. Primer pairs were designed using Primer 3 [72]. Details of the primer sequences are given in additional file 1 (Table 1) and were designed according to reference [73]. The designed primers shared $100 \%$ homology with the target sequence but no significant homology with other sequences. 
The PCR program consisted of one preincubation at $94^{\circ} \mathrm{C}$ for 2 min and 40 cycles at $94^{\circ} \mathrm{C}$ for $30 \mathrm{~s}, 55^{\circ} \mathrm{C}$ for $30 \mathrm{~s}$ $\left(50^{\circ} \mathrm{C}\right.$ for $1 \mathrm{~min}$ for PAR 1$), 68^{\circ} \mathrm{C}$ for $1 \mathrm{~min}(3 \mathrm{~min}$ for PAR1), and $68^{\circ} \mathrm{C}$ for $5 \mathrm{~min}$. All PCR reactions were performed with a Robocycler Gradient 96 with a heated lid (Stratagene, La Jolla, CA) in $50 \mu \mathrm{l}$ of $1 \times$ PCR buffer, 1.5 $\mathrm{mM} \mathrm{MgCl} 2$, forward and reverse primers at $0.2 \mu \mathrm{M}, 200$ $\mu \mathrm{M} \mathrm{dNTP}$, and $1 \mathrm{U}$ of Taq DNA polymerase (Invitrogen). Twenty microliters of the amplification mixtures were analyzed by agarose gel electrophoresis. Beta-actin was used as positive control. Images of the PCR products were taken using the FluorChem HD digital darkroom (Alpha Innotech, San Leandro, CA) and the area under the curve was quantified using Image J software [74].

\section{Animals}

All animal experimentation described here was performed in conformity with the "Guiding Principles for Research Involving Animals and Human Beings (OUHSC Animal Care \& Use Committee protocol \#05-088I). PAR1\%[38], PAR2 $\%[75]$, and $\mathrm{C} 57 \mathrm{BL} / 6 \mathrm{~J}$ mice were used in this research. $\mathrm{C} 57 \mathrm{BL} / 6 \mathrm{~J}$ mice were used as wild type since PAR1-/- and PAR2-/- were enriched in this background.

\section{Antigen sensitization protocol}

One group of mice was sensitized with $1 \mu \mathrm{g}$ DNP4-human serum albumin (HSA) in $1 \mathrm{mg}$ alum on days $0,7,14$, and 21, intraperitoneally (i.p.). This protocol induces sustained levels of IgE antibodies up to 56 days post-sensitization [76]. One week after the last sensitization, cystitis was induced as described below.

\section{Induction of cystitis}

Acute cystitis was induced in 8 mice per group, as described previously $[27,32,48,77,78]$. Briefly, female wild type (C57BL/6J), PAR1\%, and PAR2\% mice were anesthetized (ketamine $200 \mathrm{mg} / \mathrm{kg}$ and xylazine $2.5 \mathrm{mg} /$ $\mathrm{kg}$, i.p.), then transurethrally catheterized (24 Ga.; 3/4 in; Angiocath, Becton Dickson, Sandy, Utah), and the urine was drained by applying slight digital pressure to the lower abdomen. The urinary bladders were instilled with $200 \mu \mathrm{l}$ of one of the following substances: pyrogen-free saline, SP $(10 \mu \mathrm{M})$, Escherichia coli LPS strain 055:B5 (Sigma, St. Louis, MO; $100 \mu \mathrm{g} / \mathrm{ml}$ ), antigen (in sensitized mice; DNP4-OVA $1 \mu \mathrm{g} / \mathrm{ml}$ ), control inactive peptide (LRGILS [55]), or PAR- activating peptides (PAR1-AP = SFFLRN [55]; PAR2-AP = SLIGRL [55]; and PAR4-AP = AYPGKF [79]). Substances were infused at a slow rate to avoid trauma and vesicoureteral reflux (18). To ensure consistent contact of substances with the bladder, infusion was repeated twice within a 30-min interval and a 1$\mathrm{ml}$ TB syringe was kept on the catheter end to retain the intravesical solution for at least for 1 hour. The catheter was removed, and mice were allowed to void normally. Twenty-four hours after instillation, mice were euthanized with pentobarbital (200 mg/kg, i.p.), and the bladders were removed rapidly.

\section{Quantification of inflammation}

H\&E stained sections were visualized under microscope (Eclipse E600, Nikon, Lewisville, TX). All tissues were photographed at room temperature by a digital camera (DXM1200; Nikon). Exposure times were held constant when acquiring images from different groups. Images were analyzed with Image-Pro Analyzer ${ }^{\circledR}$ (Media Cybernetics Inc.; Silver Spring, MD 20910). The number of polymorphonuclear [PMNs] leukocytes was counted in a blinded fashion in 10 random fields per slide in two nonconsecutive sections per urinary bladder at $200 \times$ magnification. The number of PMNs was normalized per crosssectional area $\left(\mu \mathrm{m}^{2}\right)$. The number of infiltrate PNMs was the most reproducible sign of acute bladder inflammation and, therefore, it was used for quantification.

\section{Statistical Analysis}

Data in figures represent the mean \pm SEM of the indicated number of samples. The difference between two mean values was analyzed with the unpaired Student's t-test. Since we did not assume equal variance because the variance of PMN population is unknown, $\mathrm{p}$ values were correct using a Welch's test (GraphPad Prism software version 4.0; GraphPad Software, Inc. San Diego, CA 92130). A value of $\mathrm{p}<0.05$ was considered statistically significant.

\section{Materials}

PAR1-AP, PAR2-AP, and PAR4-AP were synthesized the Molecular Biology Resource Facility, William K. Warren Medical Research Institute, OUHSC, as carboxyl-terminal amides, purified by high-pressure liquid chromatography, and characterized by mass spectroscopy. Peptide solutions were made fresh in PBS from powder.

\section{Competing interests}

The author(s) declare that they have no competing interests.

\section{Authors' contributions}

All authors read and approved the final manuscript. RS conceived of the study and drafted the manuscript, MRD participated in the design and reviewed the morphological results, PAG participated in the experimental design and provided PAR $1 \%$ and PAR2 $\%$ mice, CKD participated in design and proper use of PAR-APS, ID participated in the experimental design, MI participated in its design and helped to draft the manuscript, REH participated in its design and helped to draft the manuscript, CS helped MRS with animal experiments, CAD performed the experiments using human urothelial cell line (J82), and MRS participated in its design, carried out the animal experiments, and removed the tissues. 


\section{Additional material}

\section{Additional file 1}

Primers for PCR. Table 1

Click here for file

[http://www.biomedcentral.com/content/supplementary/1472-

6793-7-4-S1.pdf]

\section{Acknowledgements}

Supported by National Institutes of Health grants DK 55828-0 I and DK066IOI-0I (R.S.).

\section{References}

I. Hilmy M, Campbell R, Bartlett JM, McNicol AM, Underwood MA, McMillan DC: The relationship between the systemic inflammatory response, tumour proliferative activity, T-lymphocytic infiltration and COX-2 expression and survival in patients with transitional cell carcinoma of the urinary bladder. Br J Cancer 2006, 95(9): | 234- I238.

2. Cai T, Nesi G, Boddi V, Mazzoli S, Dal Canto M, Bartoletti R: Prognostic role of the tumor-associated tissue inflammatory reaction in transitional bladder cell carcinoma. Oncol Rep 2006, I 6(2):329-334.

3. Gu J, Grossman HB, Dinney CP, Wu X: The pharmacogenetic impact of inflammatory genes on bladder cancer recurrence. Pharmacogenomics 2005, 6(6):575-584.

4. Offersen BV, Knap MM, Marcussen N, Horsman MR, HamiltonDutoit S, Overgaard J: Intense inflammation in bladder carcinoma is associated with angiogenesis and indicates good prognosis. Br J Cancer 2002, 87( I 2): | 422- I430.

5. Theoharides TC, Cochrane DE: Critical role of mast cells in inflammatory diseases and the effect of acute stress. J Neuroimmunol 2004, I 46( I-2): I- I2.

6. Boucher W, el-Mansoury M, Pang X, Sant GR, Theoharides TC: Elevated mast cell tryptase in the urine of patients with interstitial cystitis. Br J Urol 1995, 76(I):94-100.

7. Yamada T, Murayama T, Mita H, Akiyama K: Subtypes of bladder mast cells in interstitial cystitis. Int J Urol 2000, 7(8):292-297.

8. Tomaszewski JE, Landis JR, Russack V, Williams TM, Wang LP, Hardy C, Brensinger C, Matthews YL, Abele ST, Kusek JW, et al:: Biopsy features are associated with primary symptoms in interstitial cystitis: results from the interstitial cystitis database study. Urology 200I, 57(6 SuppI I):67-8I.

9. D'Andrea MR, Saban MR, Gerard NP, Wershil BK, Saban R: Lack of neurokinin-I receptor expression affects tissue mast cell numbers but not their spatial relationship with nerves. $A m J$ Physiol Regul Integr Comp Physiol 2005, 288(2):R49I-500.

10. Saban R, Gerard NP, Saban MR, Nguyen NB, DeBoer DJ, Wershil BK: Mast cells mediate substance $P$-induced bladder inflammation through an NK(I) receptor-independent mechanism. Am J Physiol Renal Physiol 2002, 283(4):F6I6-629.

II. Saban R, Saban MR, Nguyen NB, Hammond TG, Wershil BK: Mast cell regulation of inflammation and gene expression during antigen-induced bladder inflammation in mice. Physiol Genomics 200I, 7(I):35-43.

12. Ustinova EE, Gutkin DW, Pezzone MA: Sensitization of Pelvic Nerve Afferents and Mast Cell Infiltration in the Urinary Bladder Following Chronic Colonic Irritation is Mediated by Neuropeptides. Am J Physiol Renal Physiol 2006.

13. Cao J, Boucher W, Kempuraj D, Donelan JM, Theoharides TC: Acute stress and intravesical corticotropin-releasing hormone induces mast cell dependent vascular endothelial growth factor release from mouse bladder explants. J Urol 2006, I 76(3): | 208-1213.

14. Bouchelouche K, Bouchelouche P: Cysteinyl leukotriene D4 increases human detrusor muscle responsiveness to histamine. J Urol 2006, I 76(I):36I-366.

15. Okragly AJ, Niles AL, Saban R, Schmidt D, Hoffman RL, Warner TF, Moon TD, Uehling DT, Haak-Frendscho M: Elevated tryptase, nerve growth factor, neurotrophin-3 and glial cell linederived neurotrophic factor levels in the urine of interstitial cystitis and bladder cancer patients. I Urol 1999, I 6 I (2):438-44I. discussion 44I-432.

16. Vergnolle N, Cellars L, Mencarelli A, Rizzo G, Swaminathan S, Beck P, Steinhoff M, Andrade-Gordon P, Bunnett NW, Hollenberg MD, et al.: $A$ role for proteinase-activated receptor-I in inflammatory bowel diseases. Journal of Clinical Investigation 2004, I I 4( I 0): I 444.

17. Cenac N, Garcia-Villar R, Ferrier L, Larauche M, Vergnolle N, Bunnett NW, Coelho AM, Fioramonti J, Bueno L: Proteinase-activated receptor-2-induced colonic inflammation in mice: possible involvement of afferent neurons, nitric oxide, and paracellular permeability. J Immunol 2003, I 70(8):4296-4300.

18. Schmidlin F, Amadesi S, Dabbagh K, Lewis DE, Knott P, Bunnett NW, Gater PR, Geppetti P, Bertrand C, Stevens ME: Protease-activated receptor 2 mediates eosinophil infiltration and hyperreactivity in allergic inflammation of the airway. J Immunol 2002, I 69(9):5315-532I.

19. Steinhoff M, Vergnolle N, Young SH, Tognetto M, Amadesi S, Ennes HS, Trevisani M, Hollenberg MD, Wallace JL, Caughey $\mathrm{GH}$, et al.: Agonists of proteinase-activated receptor 2 induce inflammation by a neurogenic mechanism. Nat Med 2000, 6(2): $151-158$

20. Ossovskaya VS, Bunnett NW: Protease-activated receptors: contribution to physiology and disease. Physiol Rev 2004, 84(2):579-62I.

21. Amadesi S, Nie J, Vergnolle N, Cottrell GS, Grady EF, Trevisani M, Manni C, Geppetti P, McRoberts JA, Ennes H, et al.: Protease-activated receptor 2 sensitizes the capsaicin receptor transient receptor potential vanilloid receptor I to induce hyperalgesia. J Neurosci 2004, 24( I 8):4300-43।2.

22. Reed DE, Barajas-Lopez C, Cottrell G, Velazquez-Rocha S, Dery O, Grady EF, Bunnett NW, Vanner S: Mast cell tryptase and proteinase-activated receptor $\mathbf{2}$ induce hyperexcitability of guinea pig submucosal neurons. J Physiol 2003:10. III3/jphysiol.2002.032011.

23. Vergnolle N, Wallace JL, Bunnett NW, Hollenberg MD: Proteaseactivated receptors in inflammation, neuronal signaling and pain. Trends Pharmacol Sci 200I, 22(3): I46-I52.

24. Vergnolle N, Bunnett NW, Sharkey KA, Brussee V, Compton SJ, Grady EF, Cirino G, Gerard N, Basbaum Al, Andrade-Gordon P, et al.: Proteinase-activated receptor-2 and hyperalgesia: $A$ novel pain pathway. Nat Med 200I, 7(7):82I-826.

25. Hollenberg D, Compton S: International Union of Pharmacology. XXVIII. Proteinase-Activated Receptors. Pharmacol Reviews 2002, 54:203-217.

26. Vergnolle N: Review article: proteinase-activated receptors novel signals for gastrointestinal pathophysiology. Aliment Pharmacol Ther 2000, I4(3):257-266.

27. D'Andrea MR, Saban MR, Nguyen NB, Andrade-Gordon P, Saban R: Expression of protease-activated receptor- $\mathrm{I},-2,-3$, and -4 in control and experimentally inflamed mouse bladder. $\mathrm{Am} J$ Pathol 2003, I 62(3):907-923.

28. Sakai T, Noguchi M, Kisiel W: Tumor cells augment the factor Xa-catalyzed conversion of prothrombin to thrombin. Haemostasis 1990, 20(3): 125-135.

29. Lummen G, Virchow S, Rumenapp U, Schmidt M, Wieland T, Otto T, Rubben $\mathrm{H}$, Jakobs $\mathrm{KH}$ : Identification of $\mathbf{G}$ protein-coupled receptors potently stimulating migration of human transitional-cell carcinoma cells. Naunyn Schmiedebergs Arch Pharmacol 1997, 356(6):769-776.

30. McHowat J, Creer MH, Rickard A: Stimulation of protease activated receptors on $\mathrm{RT} 4$ cells mediates arachidonic acid release via $\mathbf{C a 2 +}$ independent phospholipase A2. J Urol 200I, I 65(6 Pt I):2063-2067.

31. Dattilio A, Vizzard MA: Up-regulation of protease activated receptors in bladder after cyclophosphamide induced cystitis and colocalization with capsaicin receptor (VRI) in bladder nerve fibers. J Urol 2005, I 73(2):635-639.

32. Saban MR, Nguyen NB, Hammond TG, Saban R: Gene expression profiling of mouse bladder inflammatory responses to LPS, substance $\mathbf{P}$, and antigen-stimulation. Am J Pathol 2002, I 60(6):2095-2 I I0.

33. Saito K, Muto T, Tomimori Y, Maruoka H, Tanaka T, Fukuda Y: Human chymase stimulates $\mathrm{Ca}+$ signaling in human polymorphonuclear cells. Immunology letters 2003, 89(2-3): |6 |-I65. 
34. Schechter NM, Brass LF, Lavker RM, Jensen PJ: Reaction of mast cell proteases tryptase and chymase with protease activated receptors (PARs) on keratinocytes and fibroblasts. J Cell Physiol 1998, I 76(2):365-373.

35. Ui H, Andoh T, Lee JB, Nojima H, Kuraishi Y: Potent pruritogenic action of tryptase mediated by PAR-2 receptor and its involvement in anti-pruritic effect of nafamostat mesilate in mice. Eur J Pharmacol 2006, 530(I-2): I72-178.

36. Kelso EB, Lockhart JC, Hembrough T, Dunning L, Plevin R, Hollenberg MD, Sommerhoff CP, McLean JS, Ferrell WR: Therapeutic promise of proteinase-activated receptor-2 antagonism in joint inflammation. J Pharmacol Exp Ther 2006, 3 I 6(3): I017-1024.

37. Noorbakhsh F, Tsutsui S, Vergnolle N, Boven LA, Shariat N, Vodjgani M, Warren KG, Andrade-Gordon P, Hollenberg MD, Power C: Proteinase-activated receptor $\mathbf{2}$ modulates neuroinflammation in experimental autoimmune encephalomyelitis and multiple sclerosis. J Exp Med \%R 101084/jem20052/48 2006 203(2):425-435

38. Darrow AL, Fung-Leung WP, Ye RD, Santulli RJ, Cheung WM, Derian CK, Burns CL, Damiano BP, Zhou L, Keenan CM, et al.: Biological consequences of thrombin receptor deficiency in mice. Thromb Haemost 1996, 76(6):860-866.

39. Junge $C E$, Sugawara $T$, Mannaioni G, Alagarsamy S, Conn PJ, Brat DJ, Chan PH, Traynelis SF: The contribution of protease-activated receptor I to neuronal damage caused by transient focal cerebral ischemia. Proc Natl Acad Sci USA 2003, I00(22): I3019-13024.

40. Lindner JR, Kahn ML, Coughlin SR, Sambrano GR, Schauble E, Bernstein D, Foy D, Hafezi-Moghadam A, Ley K: Delayed onset of inflammation in protease-activated receptor-2-deficient mice. J Immunol 2000, I 65( I I):6504-65 I0.

4I. Camerer E, Kataoka H, Kahn M, Lease K, Coughlin SR: Genetic evidence that protease-activated receptors mediate factor $X a$ signaling in endothelial cells. I Biol Chem 2002, 277(18): | $608|-| 6087$.

42. Kawagoe J, Takizawa T, Matsumoto J, Tamiya M, Meek SE, Smith AJ, Hunter GD, Plevin R, Saito N, Kanke T, et al.: Effect of proteaseactivated receptor- 2 deficiency on allergic dermatitis in the mouse ear. Japanese journal of pharmacology 2002, 88(I):77-84.

43. Su X, Camerer E, Hamilton JR, Coughlin SR, Matthay MA: Proteaseactivated receptor- 2 activation induces acute lung inflammation by neuropeptide-dependent mechanisms. I Immunol 2005, I 75(4):2598-2605.

44. Kawabata A, Kawao N, Kitano T, Matsunami M, Satoh R, Ishiki T, Masuko T, Kanke T, Saito N: Colonic hyperalgesia triggered by proteinase-activated receptor-2 in mice: involvement of endogenous bradykinin. Neurosci Lett 2006, 402(I-2): 167-I72.

45. Nakahara T, Kubota Y, Saito M, Sakamoto K, Ishii K: Protease-activated receptor-2-mediated contraction of urinary bladder is enhanced in cyclophosphamide-treated rats. Naunyn Schmiedebergs Arch Pharmacol 2004, 369(2):21 2-219.

46. de Garavilla L, Vergnolle N, Young SH, Ennes H, Steinhoff M, Ossovskaya VS, D'Andrea MR, Mayer EA, Wallace JL, Hollenberg MD, et al.: Agonists of proteinase-activated receptor I induce plasma extravasation by a neurogenic mechanism. Br J Pharmacol 200I, 133(7):975-987.

47. Saban R, Saban MR, Nguyen NB, Lu B, Gerard C, Gerard NP, Hammond TG: Neurokinin-I (NK-I) receptor is required in antigen-induced cystitis. Am J Pathol 2000, I 56:775-780.

48. Saban MR, Saban R, Hammond TG, Haak-Frendscho M, Steinberg H, Tengowski MW, Bjorling DE: LPS-sensory peptide communication in experimental cystitis. Am J Physiol Renal Physiol 2002, 282(2):F202-210.

49. Abraham $D$, Oster $H$, Huber M, Leitges M: The expression pattern of three mast cell specific proteases during mouse development. Mol Immunol 2007, 44(5):732-740.

50. Kim DK, Lee YM: Requirement of c-jun transcription factor on the mouse mast cell protease- 6 expression in the mast cells. Arch Biochem Biophys 2004, 43 I (I):7I-78.

5I. Wong GW, Yasuda S, Morokawa N, Li L, Stevens RL: Mouse chromosome 17A3.3 contains thirteen genes that encode functional tryptic-like serine proteases with distinct tissue and cell expression patterns. I Biol Chem 2003.

52. Funaba M, Ikeda T, Murakami M, Ogawa K, Nishino Y, Tsuchida K, Sugino $\mathrm{H}$, Abe $\mathrm{M}$ : Transcriptional regulation of mouse mast cell protease-7 by TGF-beta. Biochimica et biophysica acta 2006, 1759(3-4): 166-170.

53. Oikonomopoulou K, Hansen KK, Saifeddine M, Tea I, Blaber M, Blaber SI, Scarisbrick I, Andrade-Gordon P, Cottrell GS, Bunnett NW, et al.: Proteinase-activated receptors, targets for kallikrein signaling. J Biol Chem 2006, 28 I (43):32095-32 I I 2 .

54. de Groat WC: Integrative control of the lower urinary tract: preclinical perspective. $\mathrm{Br} J$ Pharmacol 2006, I47(Suppl 2):S25-40.

55. Macfarlane SR, Seatter MJ, Kanke T, Hunter GD, Plevin R: Proteinase-activated receptors. Pharmacological reviews 200I, 53(2):245-282.

56. Ludeman MJ, Zheng YW, Ishii K, Coughlin SR: Regulated shedding of PARI N-terminal exodomain from endothelial cells. J Bio Chem 2004, 279(18): 18592-18599.

57. Nakahara T, Kubota Y, Mitani A, Maruko T, Sakamoto K, Ishii K: Protease-activated receptor-2-mediated contraction in the rat urinary bladder: the role of urinary bladder mucosa. Naunyn Schmiedebergs Arch Pharmacol 2003, 367(2):21 I-2 I3.

58. Kubota Y, Nakahara T, Mitani A, Maruko T, Saito M, Sakamoto K, Ishii $\mathrm{K}$ : Possible involvement of $\mathrm{Ca2}+$-independent phospholipase $A 2$ in protease-activated receptor-2-mediated contraction of rat urinary bladder. Naunyn Schmiedebergs Arch Pharmacol 2003, 367(6):588-591.

59. Portell C, Rickard A, Vinson S, McHowat J: Prostacyclin production in tryptase and thrombin stimulated human bladder endothelial cells: effect of pretreatment with phospholipase A2 and cyclooxygenase inhibitors. J Urol 2006, 176(4 Pt I): $1661-1665$

60. Rickard A, Portell C, Kell PJ, Vinson SM, McHowat J: Protease-activated receptor stimulation activates a $\mathrm{Ca2}+$-independent phospholipase A2 in bladder microvascular endothelial cells. American journal of physiology 2005, 288(4):F7|4-72I

61. Rickard A, McHowat J: Phospholipid metabolite production in human urothelial cells after protease-activated receptor cleavage. American journal of physiology 2002, 283(5):F944-95I.

62. Major CD, Santulli RJ, Derian CK, Andrade-Gordon P: Extracellular mediators in atherosclerosis and thrombosis: lessons from thrombin receptor knockout mice. Arterioscler Thromb Vasc Biol 2003, 23(6):93।-939.

63. Coughlin SR: Protease-activated receptors in hemostasis, thrombosis and vascular biology. J Thromb Haemost 2005, 3(8): $|800-18| 4$.

64. Tang H, Low B, Rutherford SA, Hao Q: Thrombin induces endocytosis of endoglin and type-II TGF-beta receptor and downregulation of TGF-beta signaling in endothelial cells. Blood 2005, 105(5): 1977-1985.

65. Hamilton JR, Moffatt JD, Frauman AG, Cocks TM: Protease-activated receptor (PAR) I but not PAR2 or PAR4 mediates endothelium-dependent relaxation to thrombin and trypsin in human pulmonary arteries. J Cardiovasc Pharmacol 200I, 38(I): I08-I I9.

66. Dery O, Corvera CU, Steinhoff M, Bunnett NW: Proteinase-activated receptors: novel mechanisms of signaling by serine proteases. Am J Physiol 1998, 274(6 Pt I):CI429-1452.

67. Kong W, McConalogue K, Khitin LM, Hollenberg MD, Payan DG, Bohm SK, Bunnett NW: Luminal trypsin may regulate enterocytes through proteinase-activated receptor 2 . Proc Natl Acad Sci USA 1997, 94(16):8884-8889.

68. Cocks TM, Fong B, Chow JM, Anderson GP, Frauman AG, Goldie RG, Henry PJ, Carr MJ, Hamilton JR, Moffatt JD: A protective role for protease-activated receptors in the airways. Nature 1999 , 398(6723): $156-160$.

69. Noorbakhsh F, Tsutsui S, Vergnolle N, Boven LA, Shariat N, Vodigani M, Warren KG, Andrade-Gordon P, Hollenberg MD, Power C: Proteinase-activated receptor 2 modulates neuroinflammation in experimental autoimmune encephalomyelitis and multiple sclerosis. J Exp Med 2006, 203(2):425-435.

70. Gatti R, Andre E, Amadesi S, Dinh TQ, Fischer A, Bunnett NW, Harrison S, Geppetti P, Trevisani M: Protease-activated receptor-2 activation exaggerates TRPVI-mediated cough in guinea pigs. J Appl Physiol 2006, I0I(2):506-5I I.

7I. Luo W, Wang Y, Hanck T, Stricker R, Reiser G: Jab I, a novel protease-activated receptor-2 (PAR-2)-interacting protein, is involved in PAR-2-induced activation of activator protein-I. J Biol Chem 2006, 28 I ( I 2):7927-7936. 
72. [http://frodo.wi.mit.edu/cgi-bin/primer3/primer3 www.cgi].

73. Asokananthan N, Graham PT, Fink J, Knight DA, Bakker AJ, McWilliam AS, Thompson PJ, Stewart GA: Activation of protease-activated receptor (PAR)-I, PAR-2, and PAR-4 stimulates IL-6, IL-8, and prostaglandin E2 release from human respiratory epithelial cells. J Immunol 2002, I68(7):3577-3585.

74. [http://rsb.info.nih.gov/ii/]

75. Damiano BP, Cheung WM, Santulli RJ, Fung-Leung WP, Ngo K, Ye RD, Darrow AL, Derian CK, de Garavilla L, Andrade-Gordon P: Cardiovascular responses mediated by protease-activated receptor-2 (PAR-2) and thrombin receptor (PAR-I) are distinguished in mice deficient in PAR-2 or PAR-I. J Pharmacol Exp Ther 1999, 288(2):67I-678.

76. Haak-Frendscho M, Saban R, Shields RL, Jardieu PM: Anti-immunoglobulin $E$ antibody treatment blocks histamine release and tissue contraction in sensitized mice. Immunology 1998, 94(I): II5-12I.

77. Dozmorov I, Saban MR, Gerard NP, Lu B, Nguyen NB, Centola M, Saban R: Neurokinin I receptors and neprilysin modulation of mouse bladder gene regulation. Physiol Genomics 2003, I 2(3):239-250.

78. Saban MR, Nguyen NB, Hurst RE, Saban R: Gene expression profiling of inflammatory bladder disorders. Expert Rev Mol Diagn 2003, 3(2):217-235.

79. Faruqi TR, Weiss EJ, Shapiro MJ, Huang W, Coughlin SR: Structurefunction analysis of protease-activated receptor 4 tethered ligand peptides. Determinants of specificity and utility in assays of receptor function. J Biol Chem 2000, 275(26): 19728-19734.

Publish with Bio Med Central and every scientist can read your work free of charge

"BioMed Central will be the most significant development for disseminating the results of biomedical research in our lifetime. "

Sir Paul Nurse, Cancer Research UK

Your research papers will be:

- available free of charge to the entire biomedical community

- peer reviewed and published immediately upon acceptance

- cited in PubMed and archived on PubMed Central

- yours - you keep the copyright

Submit your manuscript here:

http://www.biomedcentral.com/info/publishing_adv.asp
BioMedcentral 